\title{
The New Right
}

Politics, Markets and Citizenship 
Also by Desmond S. King

The State and the City

(with Ted Robert Gurr) 


\title{
The New Right \\ Politics, Markets and Citizenship
}

\author{
Desmond S. King
}

Department of Politics, University of Edinburgh

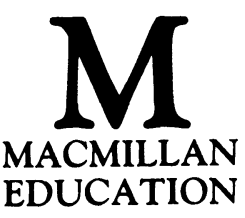




\section{(C) Desmond S. King 1987}

All rights reserved. No reproduction, copy or transmission of this publication may be made without written permission.

No paragraph of this publication may be reproduced, copied or transmitted save with written permission or in accordance with the provisions of the Copyright Act 1956 (as amended), or under the terms of any licence permitting limited copying issued by the Copyright Licensing Agency, 7 Ridgmount Street, London WC1E7AE.

Any person who does any unauthorised act in relation to this publication may be liable to criminal prosecution and civil claims for damages.

First published 1987

Published by

MACMILLAN EDUCATION LTD

Houndmills, Basingstoke, Hampshire RG21 2XS

and London

Companies and representatives

throughout the world

British Library Cataloguing in Publication Data

King, Desmond S.

The new right: politics, markets and

citizenship.

1. Conservatism

I. Title

320.' 52

JC571

ISBN 978-0-333-42075-1 ISBN 978-1-349-18864-2 (eBook)

DOI 10.1007/978-1-349-18864-2 


\section{Contents}

List of Tables $\quad$ ix

$\begin{array}{ll}\text { List of Figures } & \text { ix }\end{array}$

Acknowledgements $\quad$ x

1 Introduction 1

2 Liberalism, Conservatism and the New Right 7 Introduction $\quad 7$

The meaning of the New Right 8

$\begin{array}{ll}\text { Liberalism } & 9\end{array}$

Traditional liberal values $\quad 9$

Public choice school $\quad 11$

Libertarianism $\quad 12$

The work of F. A. Hayek 14

Conservatism $\quad 16$

Social and moral conservatism: the erosion of social citizenship rights $\quad 17$

Social and populist authoritarianism 21

Liberalism and conservatism: contradiction and

Conclusion $\quad 26$

3 Politics and the New Right: The Primacy of Freedom $\quad 28$

Introduction $\quad 28$

Freedom and the New Right $\quad 28$

The meaning of freedom

Freedom and the market $\quad 31$

Market outcomes 34 
Freedom and the state

The necessity of inequality for market processes $\quad 38$

Equality and state policy $\quad 40$

The Hayekian critique of social justice 40

Does the welfare state reduce freedom? 45

Conclusion $\quad 48$

4 The Decline of the Keynesian Welfare State

Consensus

Introduction

The Keynesian welfare state: Britain

The welfare state $\quad 50$

Keynesian economic principles $\quad 53$

Nationalisation $\quad 55$

The Keynesian welfare state: the United States 57

American welfare provision $\quad 57$

Keynesian economics in the United States $\quad 59$

Regulation $\quad 60$

The Keynesian welfare state consensus under attack 63

Political overload 63

Criticisms of Keynesian economics $\quad 65$

Monetarism $\quad 65$

$\begin{array}{ll}\text { Conclusion } & 68\end{array}$

5 Liberal Economics 1: The Market 70

$\begin{array}{ll}\text { Introduction } & 70\end{array}$

The market in economic theory $\quad 71$

The perfect competition model $\quad 76$

Public goods, state intervention and the market $\begin{array}{ll}\text { order } & 80\end{array}$

The state and capitalism: can the market operate with a minimal state? $\quad 85$

$\begin{array}{lr}\text { Conclusion } & 89\end{array}$

6 Liberal Economics 2: Public Choice Theory 91

Introduction $\quad 91$

The meaning of public choice theory 92

The scope of public choice analysis $\quad 92$

The assumptions of public choice analysis $\quad 94$ 
The contribution of public choice theory 95

Preference aggregation $\quad 95$

The prisoners' dilemma: the necessity of

collective action and the problem of collective action $\quad 97$

$\begin{array}{lr}\text { Public choice analysis and politics } & 100\end{array}$

Political parties and voters 100

The behaviour of bureaucrats 102

The New Right and public choice analysis:

policies for reform 104

$\begin{array}{ll}\text { Conclusion } & 108\end{array}$

7 The Thatcher Government and State Activity 110

Introduction 110

The conservative party 111

The three traditions of the Conservative Party 111

The policies of the Thatcher Government 113

Monetarism 113

Rolling back the state: public spending and

$\begin{array}{ll}\text { government priorities } & 120\end{array}$

Privatisation: state revenues and market

solutions 123

Interpretations of the Thatcher Government 126

The Thatcher Government and pragmatic politics $\quad 127$

$\begin{array}{ll}\text { Authoritarian populism } & 128\end{array}$

Conclusion: a liberal government? 133

8 The Reagan Administration $\quad 136$

Introduction 136

Ronald Reagan and the Republican Party 137

The policy objectives of the Reagan Administration 141

Supply-side economics 141

Supply-side economics implemented $\quad 144$

Cutting public social expenditure and increasing defence 148

The Reagan Administration and deregulation $\quad 155$

Conclusion: ending state intervention? 159

The institutionalisation of liberal priorities $\quad 160$

Attacking social citizenship rights 161 
viii Contents

9 Social Citizenship Rights in the Welfare State 164 $\begin{array}{ll}\text { Introduction } & 164\end{array}$

Social citizenship rights and the welfare state 164

The work of T. H. Marshall 165

The nature of the welfare state 168

Marginal versus institutional welfare states $\quad 170$

Welfare state producers and consumers 173

Defending citizenship rights 174

$\begin{array}{ll}\text { Conclusions } & 177\end{array}$

10 Markets and Citizenship: A New Agenda 178

Introduction: Markets versus Planning - A New

Debate? 178

Markets and consumption 179

Markets and economic policy 181

A revived Keynesianism? 182

Labour market policy 186

Conclusion: markets and citizenship 191

Epilogue: Citizenship Against Markets 196

$\begin{array}{ll}\text { Bibliography } & 199\end{array}$

$\begin{array}{ll}\text { Index } & 211\end{array}$ 


\section{List of Tables}

7.1 Economic indicators for the Thatcher Government 116

7.2 Public expenditure under the Thatcher Government 122

7.3 Privatisation under the Thatcher Government 125

7.4 Manual and non-manual support for political parties 131

8.1 Economic indicators for the Reagan Administration 148

8.2 Public expenditure under the Reagan Administration 153

\section{List of Figures}

2.1 Levels of state intervention

6.1 The prisoners' dilemma

8.1 The Laffer curve 


\section{Acknowledgements}

A number of people have helped me in the production of this book. I have benefited greatly from conversations with John Holmwood. I doubt whether I have met all his criticisms, but through our discussions the text has been improved immensely. Henry Drucker and Malcolm Anderson also deserve special thanks as they both read through the entire manuscript and made many useful comments.

I am grateful to several other colleagues for reading and commenting upon various portions of the manuscript. They include Nigel Bowles, Alice Brown, Jerry Goldman, Robert Goodin, Richard Parry and Jeremy Waldron. My thanks also to Steven Kennedy for his patience and encouragement with this book.

The author wishes to thank Pergamon Press for kindly giving permission for the use of copyright material for an abridged form of Table 3.1, reprinted with permission from Anthony Heath, Roger Jowell and John Curtice (1985) How Britain Votes.

Desmond S. King 